\title{
Explaining Crime in Metropolitan and Non-Metropolitan Communities
}

\author{
Dr. L. Edward Wells \\ Professor \\ Department of Criminal Justice \\ Illinois State University \\ Normal, Illinois USA 61790-5250 \\ Phone: 309-438-2989 \\ Email: ewells@ilstu.edu \\ Dr. Ralph A. Weisheit \\ Professor \\ Department of Criminal Justice \\ Illinois State University \\ Normal, Illinois USA 61790-5250 \\ Phone: 309-438-3849 \\ Email: raweish@ilstu.edu
}

Contact author - Ralph A. Weisheit: raweish@ilstu.edu 0103094383849

\begin{abstract}
Traditional urban theories of community crime development increasingly are being adapted and evaluated for their relevance to the crime problems of smaller and less urban settings. Most notable of these have been social disorganization theory and civic community theory. This paper compares these two major theoretical frameworks for explaining community-level variations in crime, using county-level data on crime rates merged with data on the economic, geographic, population, and ecological features of counties in the U.S. The study finds that both traditional social disorganization and civic community theories are good predictors of some, but not all, types of crime, in the largest metropolitan areas. However, their predictive power declines substantially when applied to the most rural communities.
\end{abstract}

Keywords: Rural Crime, Social Disorganization Theory, Civic Community Theory, Violent Crime, Property Crime, Drug Arrests, Juvenile Arrests. 


\section{Introduction}

Over the last two decades, there has been a strong resurgence of interest by both researchers and policy-makers in community-level explanations of crime problems and community-level strategies for reducing crime. This resurgence comes after several decades during which a community-level focus on crime was almost entirely absent following the fall from criminological prominence in the 1950s of social disorganization theory and its associated ecological models. Anomie theory rose to largely dominate macro-level thinking about crime in the 1960s, shifting national policy-making and research attention to broadly framed structural questions about American society generally, with little attention to variations among local communities. At about the same time, micro-level theories about individual differences in criminal behavior, based on theories of social learning and social control and derived from large questionnaire survey studies of anonymous, decontextualized individuals, came to dominate criminological efforts to explain smaller variations in crime rates. This micro-level effort to explain crime as due to variations in the expression of human nature and latent traits gave little attention to the communities and social structures in which the respondents were embedded. Consequently, community-based analyses of social phenomena like crime came to be generally viewed as irrelevant and outmoded forms of analysis. As Massey (2001) observed in sociology, community-based analysis thus became largely a "prodigal paradigm" in the 1960s, spending the next several decades exiled from mainstream social science.

In the late 1980s, however, community-level analyses began reappearing in criminology (e.g., Byrne \& Sampson 1986; Reiss \& Tonry 1986). The renewed interest in community-based thinking about crime was not unique to criminology but part of a broader rediscovery of the theoretical importance of community by policy-makers, academics, and practitioners across a variety of fields, from sociology to medicine to international banking. By the final decade of the twentieth century, community-based approaches were academically in vogue, theoretically fashionable, and politically appealing. As Sampson (1999:241) noted:

\section{Community seems to be the modern elixir for much of what ails American society. Indeed, as we approach a new century and reflect on the wrenching social changes that have shaped our recent past, calls for a return to community values are everywhere. From politicians to private foundations to real estate developers to criminal justice officials to communitarians, the appeal of community is ubiquitous.}

Along with renewed criminological attention to the idea of community for explaining variations in crime rates, a notable shift in criminal justice policy also occurred, leading to new crime-control policies and administrative models centered on the identification of key community attributes that might put them at differential risk for high crime rates, proliferation of street gangs, and expanding drug abuse problems. The most familiar example of this shift 
toward community-oriented policies among criminal justice decision-makers was the dramatic ascendance of the Community-Oriented Policing movement of the 1990s, widely promoted as a major shift in the administration of American policing, as well as heavily funded by the federal government and actively exported to policing organizations around the world (e.g., Greene \& Mastrofski 1991).

In theoretical terms, the renewal of community-focused analysis in criminology has resulted in at least three important developments in criminological research and theory. First has been the resurrection and revitalization of social disorganization theory, which was largely abandoned in the 1950s as theoretically outmoded and empirically disproved, but revived in the 1990s as a dominant perspective for studying community variations in crime. Developed in the early decades of the $20^{\text {th }}$ century by Park and Burgess (Park, Burgess, \& McKenzie 1925; Park, 1936) \& Shaw \& McKay (1942) as the theoretical core of the "Chicago school" in criminology, social disorganization theory is widely remembered for its ecological framework borrowed from plant ecology and for its imaginative concentric zones model of urban development and crime distribution. By the 1950s, however, the theory became increasingly viewed as theoretically inadequate, criticized for its incomplete conceptualization and the apparent empirical disconfirmation of many of its key theoretical propositions, particularly the concentric zones model, which seemed to have been too dependent on historically unique features of Chicago neighborhoods in the early $20^{\text {th }}$ century and not generalizable to other times and places. For several decades, beginning in the mid-1960s, social disorganization theory was effectively consigned to the historical dustbin of influential-but-flawed theories of crime - interesting but not up to the standards of current social science.

With the revival of community-level interest in urban crime patterns in the late 1980s, however, thoughtful reconsiderations of social disorganization theory were offered independently by Robert Bursik (1988, 1999; Bursik \& Grasmick 1993; 1995) \& Robert Sampson $(1987 ; 1991 ; 1993 ; 1999 ; 2001 ; 2002)$. They retained the original insights of the theory but reformulated it to provide a more rigorous conceptualization of these insights and more empirically measurable and testable definitions of key concepts and premises. Bursik reformulated the original version of social disorganization theory, explicating the multi-level, social network nature of community organization and distinguishing clearly between the processes of community disorganization and the demographic conditions that precede it. For Bursik, social disorganization refers to the weakening of networks of social ties and interpersonal relationships that connect community members to each other and to local groups, which lead to a weakening of informal control by the community, resulting in increased levels of deviant behavior. By connecting social disorganization theory to contemporary models of urban sociology (e.g., Kasarda \& Janowitz 1974; Hunter 1985), Bursik developed what has come to be identified as the "Systemic Model" of social (dis)organization and which has prompted a sizeable body of new empirical research. 


\section{Explaining Crime in Metropolitan and Non-Metropolitan Communities - Wells and Weisheit}

Robert Sampson's variant of social disorganization theory provided a similar yet distinctive explanation, but drew more explicitly on recent theory and research on "social capital" to specify more fully how disorganization in communities' residential networks weakened their ability to respond to neighborhood problems and to exercise control over disorderly or illegal activities on neighborhood streets - resulting in a loss of collective efficacy of neighborhood residents to mobilize for communal problem solving. Sampson also provided an explication of the social control and social capital aspects of social disorganization theory, developing and testing direct empirical measures of these processes, and resulting in what is now known as the "collective efficacy" theory of neighborhood social control (Sampson \& Groves 1989; Sampson, Raudenbush, \& Earls 1997).

Beyond the considerable research produced by Bursik and Sampson themselves, their explications of social disorganization have prompted a significant boom in research by other scholars on community-level dynamics in crime variations and a dramatically expanded interest by political policy-makers in applying community-level models to the reduction of crime rates. The bulk of the recent ecological and community-level research, as in the original social disorganization research, has been focused mainly on crime in urban neighborhoods. These modern variations on traditional social disorganization share the original version's focus on large urban areas in which the unit of analysis is the small neighborhood. These new approaches, however, involve a methodology that is ill suited to studying rural and small-town communities in which the meaningful area in which daily life activities are conducted may extend to the boundaries of the county. These new approaches to social disorganization also rely on a methodology that limits, for practical reasons, the number of communities that may be studied simultaneously, and are thus ill suited to examining broad national patterns. It is perhaps premature to discount traditional conceptualizations of social disorganization that, as will be shown below, can draw on wider units of analysis than the local neighborhood and which can study the issue on a national level.

A second notable development in the community-level revival in criminology has been a growing effort to expand community-level studies of crime patterns beyond the metropolis (e.g., Barnett \& Mencken 2002; Bouffard \& Muftic 2006; Cancino 2003; Donnermeyer, Barclay, \& Jobes 2002; Jobes et al. 2004; Kaylen \& Pridemore 2011; Kposowa, Breault, \& Harrison 1995; Lee, Maume, \& Ousey 2003; Osgood \& Chambers 2000; Petee \& Kowalski,1993; Weisheit \& Wells 2005; Wells \& Weisheit 2004). The concern is whether available urban-based community models of crime (including social disorganization theory) apply to a wider range of community types and settings, including small cities and communities in less densely populated rural areas. This extension of community-level analyses to nonmetropolitan and small town settings has raised important questions about the universality of the urban ecological or social disorganization model. Studies of crime patterns in nonmetropolitan communities provide substantial confirmation of some elements of the theory, but they also report some differences in the social dynamics of communities of different sizes and locations. These studies suggest that the 
community dynamics productive of crime and other social problems may work differently in less urbanized settings where the scale of community life and the nature of the interconnections among community residents are different. Such studies suggest that some features of the reformulated social disorganization theory may need to be revised or re-conceptualized to be fully valid and general; and they illustrate the importance for community-level research in criminology to be carried on the full-range of community types, sizes, and locations.

A third important development has been use of alternative theoretical models of community development and organization drawn from outside the traditional criminological framework of social disorganization theory. These represent an attempt to introduce new ideas and insights drawn from other social science fields, including political sociology. The most notable new alternative perspective on community development and organization is Lee's elaboration and application of civic community theory, using a model of community dynamics drawn from community development and political sociological theories of "the civil society" as well as from recent scholarship on the concept of "social capital." Civic community theory is presented as a broader framework that allows for analyzing community-crime variations across the full range of community types and sizes. While conceptually similar to social disorganization theory in emphasizing social ties and memberships, civic community theory is more broadly focused on the organizational, political, economic structures of communities, as well as the behavioral patterns of residents' participation in civic activities, rather than simply on the interpersonal networks of attachments among neighbors. Research by Lee and colleagues (e.g., Lee 2008; Lee \& Bartkowski 2004a; 2004b; Lee, Maume, \& Ousey 2003; Lee \& Thomas 2010; Ousey \& Lee 2010) amply documents the empirical testability and the theoretical utility of a civic community explanation for community crime variations.

There is some notable conceptual overlap between the social disorganization and civic community models in that both emphasize the importance of residential stability and of interpersonal connections among community members in maintaining a strong community "social fabric" necessary for effective social control, problem solving, and order maintenance. However, they place somewhat different emphases in going beyond these common ideas. Social disorganization theory focuses on the strength of interpersonal friendships and places greater causal weight on the community demographic conditions that are hypothesized to facilitate or hinder development of such relationships. The civic community perspective puts greater emphasis on the residents' rates of investment and participation in local institutions and less on the racial/ethnic composition or family structures of neighborhoods. In theory, the form of the local economy (e.g., family vs. corporate farms, local ownership of businesses, higher levels of self-employment) is more important than the amount of wealth in the community or the overall employment level. Thus, there are important areas of divergence between the two otherwise compatible theories.

An important but unresolved issue concerns the question of what community-focused 


\section{Explaining Crime in Metropolitan and Non-Metropolitan Communities - Wells and Weisheit}

theories of crime are presumed to be explaining - i.e., what specifically is the relevant dependent variable in research based on social disorganization or civic community models? Strictly speaking, both models represent "social problems" theories, in that they seek to explain how and why undesirable conditions (including crime, gang, and delinquency problems) develop in some communities and not so much in others. The theoretical frameworks predict that social disorganization or weakened civic engagement lead to these undesirable outcomes by reducing the ability of communities to work together to solve problems, to realize common goals, to exercise social control over unwanted activities, and to maintain quality-of-life for community residents. This invariably results in higher levels of all sorts of disorderly, predatory, and deviant behaviors that are disvalued by community members but which they are unable to communally prevent. In practice, however, most studies of social disorganization have focused on violent crime, one of the rarest forms of crime accounting for only about 12 percent of the Index Crimes (based on US statistics from the FBI's Uniform Crime Report) recorded by police, or else on homicides, which make up only 0.1 percent of Index Crimes. While clearly important events for social control, these are statistically unusual events and therefore most likely to suffer from the problem of small numbers when examined in very small geographic units, such as

neighborhoods. It is reasonable to allow that sub-types of crimes might be differentially affected by different community features. Thus, the analysis that follows includes separate consideration of violent crimes, property crimes, drug arrests, and juvenile arrests.

\section{Research Questions}

This paper provides a comparative assessment of traditional social disorganization theory and civic community theory, and provides this assessment across the range of community sizes and settings, and in which county is the unit of analysis. It seeks to answer two questions about the application of these two theories to community-level variations in crime: (1) Do the patterns of effects for the two theories appear similar across different types and sizes of community settings - i.e., for small communities in rural areas as for metropolitan communities in urban areas? (2) How sensitive are the explanations of community-level crime patterns offered by the two theories to different types of crime?

In addressing these questions, the analysis contains two distinct but related tasks. First, the analysis compares application of the two theoretical models to communities of different sizes and locations on the rural-urban continuum. It assesses whether social disorganization and civic community processes seem to operate similarly for metropolitan and for nonmetropolitan communities, ranging from counties with medium-sized cities to those with no cities at all. Separate analyses are done for counties in four distinct size categories from metropolitan-urban to rural.

Second, the analysis examines how much the particular operationalization of the dependent variable (i.e., crime rates) affects the ability of social disorganization and civic community 
models to explain community variations in crime. Four different operationalizations of "crime rates" are considered here: (1) violent index crimes, (2) property index crimes, (3) drug arrests, and (4) juvenile arrests. Of concern here is whether the pattern of effects shown by social disorganization or civic community variables depends on the specific form of the crime rate variables being analyzed.

\section{Research Strategy}

The analytical perspective adopted here is explicitly comparative and configural rather than focused on simple and direct hypothesis testing of a single theoretical model. The present analysis is concerned with looking at patterns of findings across different theoretical models, different measures of crime rates, and different types of community settings, rather than testing the statistical significance of specific coefficients in a single data sample. The interest in comparative analysis is concerned with the relative predictability (or explicability) of community crime rates across different theoretical models of community crime dynamics, across different measurements of the dependent variable, and across different types of community settings. Because the two theoretical models are not mutually exclusive in theoretical content or predictions - indeed, social disorganization and civic community have important points of substantive commonality - a critical (zero-sum) test between them is not possible. Instead, we examine how each model does compared to the alternative in separately (as well as jointly) predicting variations in crime rates across communities. The aim is to assess which theoretical model works better in predicting community-level variations in crime problems. Additionally, we wish to evaluate whether these models are as effective in explaining nonmetropolitan crime rate variations in small towns and outlying areas as they are in accounting for crime differences in metropolitan urban centers. In this, the analysis is concerned with comparisons between sets of variables within a single regression analysis as well as comparisons of their effects across different regressions.

Our analytical approach to this comparison of social disorganization and civic community models is configural in that we are less interested in testing the statistical significance level of specific coefficients in a single regression equation than in the patterns of coefficients for sets of variables models across variations in dependent measures and community subsamples. While prior research relies heavily on statistical significance tests of individual coefficients to assess theoretical importance, our approach is to focus on the relative substantive significance of effects (by comparisons of standardized coefficient sizes) and on the consistency of these effects across variations in the specific variables (i.e., measures of crime rates) and the community contexts being considered. In interpreting the patterns of empirical effects (versus individual effect estimates), we consider: (1) the relative magnitudes of coefficients compared to the standardized coefficients of other independent variables (both as individual variables and as blocks of theoretically related predictors); (2) the signs of coefficients as being consistent or inconsistent with theoretical predictions from the models under consideration; (3) the contributions of 


\section{Explaining Crime in Metropolitan and Non-Metropolitan Communities - Wells and Weisheit}

theoretical groups of variables to the explained variance in community crime rates (as measured by $\mathrm{R}^{2}$ figures); (4) the consistency of effect sizes and signs across different type of crimes; and (5) the consistency of effect coefficients across the full range of community settings (from metropolitan to rural).

Rather than selecting a distinctive subsample of communities (limited to communities of a particular population size or regional location), the present analysis includes all counties in the U.S. but divides them into four categories representing distinctively diverse ecological types metropolitan areas; larger nonmetropolitan areas containing a medium-size city $(20,000$ to 50,000 population), less populous nonmetropolitan areas containing only small towns (of at least 2,500 but less than 20,000 in population size); completely rural nonmetropolitan areas (containing no towns of at least 2,500 persons).

The analysis reported here involves the population of all U.S. counties for which valid crime data are available, rather than a random sample or a nonrandom purposive or availability sample as used in most prior research. Thus, statistical significance tests are not used to identify important effects or differences. The present analysis relies on comparative substantive significance of effect coefficients, using standardized partial regression coefficients of at least 0.10 in magnitude as an evaluative benchmark. Standardized regression coefficients (Betas) are used in this analysis to measure causal/predictive effects so that the relative impact of independent variables with different metrics or units of measurement can be directly compared both within and across community subsamples. The use of standardized measures of effect is also consistent with the original theoretical models of social disorganization and civic community, neither of which makes any specific predictions about the absolute magnitude of effects, but only about the relative importance of causal factors.

For comparative purposes, it is important to include all available areas in the data set under investigation; otherwise, no direct comparisons across community types are possible (but can only be implicit). Studies analyzing rural-only or nonmetro-only samples (for which metrononmetro comparisons are inferred indirectly) are much more likely to report finding no appreciable differences in applying social disorganization theory or community-level models of crime to metro and nonmetro communities (e.g., Osgood \& Chambers 2000; Lee \& Ousey, 2001; Lee, Maume, \& Ousey 2003). In contrast, studies analyzing general, broadly inclusive community samples that include both metro and nonmetro areas in the data set are much more likely to find divergence in causal dynamics between metro and nonmetro communities (e.g. Barnett \& Mencken 2002; Petee \& Kowalski 1993).

In comparing social disorganization and civic community models, the present analysis involves the "classic" version of social disorganization theory, rather than the newer systemic or "collective efficacy" versions of the theory. In the classic version of the theory, as conceptualized and operationalized by its original developers, social disorganization is not 
observed directly but is measured indirectly through the predisposing demographic conditions in the community which produce social disorganization, namely, residential transience/instability, ethnic/racial heterogeneity, economic marginality, and family disruption. In contrast, newer explications of social disorganization theory define social disorganization sociometrically in terms of incomplete networks of interpersonal friendships among neighborhood residents and weak networks of mutual assistance relationships among neighbors. Thus far, the network version of social disorganization has been explicated only for population-dense, physically small urban subcommunities (and operationalized by small-scale surveys of local neighborhood residents), which limits its research application to other types of community settings. As a result, all recent applications of social disorganization theory beyond metropolitan urban neighborhoods (e.g., Barnett \& Mencken 2002; Bouffard \& Mufti 2006; Kaylen \& Pridemore 2010; Osgood \& Chambers 2000;) have analyzed the demographically defined "classic" version of the theory using traditional demographic measurements of the community preconditions of social disorganization, as does the present study.

\section{Research Methods}

The data set analyzed in this study was constructed by combining crime data from the FBI's Uniform Crime Reports with social, demographic, and economic data on communities from the U.S. Census supplemented with information from several additional national-level sources. The basic data on crime rates were extracted from the county-level crime statistics obtained from police departments across the U.S. by the F.B.I. in its annual Uniform Crime Reports. County-level data on crimes and arrests reported for the years 2003, 2004, and 2005 were obtained from the criminal justice data archive at the Inter-University Consortium for Political and Social Research (FBI, 2005; 2006; 2007). The numbers of crimes or arrests and the populations covered in each year's statistics were combined into three-year average annual rates for each county. Counties with less than six months of data in a year were counted as missing and excluded from the yearly computations. For this analysis, four separate crime variables were computed and included in this analysis: (1) violent crime rate (violent index crimes reported to police per 100,000 population); (2) property crime rate (nonviolent index crimes reported to police per 100,000 population); (3) drug arrest rate (all drug-related arrests recorded by police per 100,000 population); and (4) juvenile arrest rate (arrests of juvenile persons for any type of crime per 100,000 population). These represent four distinctively different types of crimes as well as two different types of crime data (crimes reported versus arrests made). As with most crime rates, the distributions of these variables are positively skewed (only slightly so for property crimes). Thus, for use in the regression analyses in this study, the crime rates were transformed by taking the square root of each, which yielded satisfactorily symmetric distributions.

Data on the ecological, social, and economic characteristics of counties were derived from U.S. Census data obtained from the County and State Data Book: 2000 published by the U.S. 


\section{Explaining Crime in Metropolitan and Non-Metropolitan Communities - Wells and Weisheit}

Census Bureau (U.S. Department of Commerce 2003), from the County Characteristics, 20002007 data available from the Inter-University Consortium for Political and Social Research (ICPSR 2007), from the Sourcebook America 2003 (ESRI 2003), and from the Religious Congregations and Membership Study 2000 (ARDA 2002; Finke and Scheitle 2005). The data for these additional variables were merged with the crime data using the county and state Federal Information Processing Standards (FIPS) codes for each county (ERS 2003).

Three groups of independent variables were selected and used in this analysis. The first group includes the control variables for the analysis - i.e., standard socio-economic variables widely identified in prior macro-level research as common correlates of crime rates and which may contribute county-level variations in crime rates extraneous to the present analysis of social disorganization or civic community processes. These control variables included the age distribution (i.e., percent of the population less than 18 years old), the education level, (i.e., percent of the adult population who graduated high school), the income level (i.e., median household income), and the regional location (South versus non-South) of the counties. These provide some statistical control for compositional and locational differences across communities that may be confounded with the theoretical predictor variables.

Social disorganization theory and civic community theory were each operationalized by a block of five variables intended to measure the key causal elements conceptualized for each theory. The social disorganization variables represented the classic theoretical precursors of social disorganization as commonly used in prior published studies of social disorganization processes. These included county-level indicators of: (1) residential instability (percent who lived in different house 5 years ago); (2) population instability (percent of population change over the last 5 years); (3) racial/ethnic heterogeneity (a heterogeneity index computed over all census-defined racial categories in the county); (4) economic disadvantage (percent of children living in poverty); and (5) family disorganization (percent of single female-headed family households). As noted above, these measure the key concepts of "classic" social disorganization theory; they do not directly measure the more recent concepts of "systemic" disorganization or collective efficacy models.

Civic community variables were selected, following the prior measurement of these processes by Lee (Lee 2006, 2008; Lee \& Thomas 2010) and by Tolbert and Lyson (Tolbert, Irwin, Lyson, \& Nucci 2002; Tolbert, Lyson, \& Irwin 1998; Lyson, Torres, \& Welsh 2001), to measure the central causal factors of: (1) residential investment in the community (percent of housing units that were owner-occupied), (2) civic engagement (percent voting in last presidential election), (3) participation in community institutions (mainline church membership rate), (4) locally-based small-scale capitalism (percent of working population that is self- 
employed) and (5) locally-based small-scale capitalism (percent of farms less than 50 acres). Table 1 shows the descriptive statistics for each of the independent variables used in this analysis.

Table 1 Descriptive Statistics on the Dependent and Independent Variables

Variables

\section{Dependent Variables}

Violent Crime Rate (SqRoot)

Property Crime Rate (SqRoot)

Drug Arrest Rate (SqRoot)

Juvenile Arrest Rate (SqRoot)

\section{$\underline{\text { Control Variables }}$}

Median Household Income (1000)

Percent under 18 years of age

Percent High School grads

South-vs-Nonsouth (0-1)

\section{$\underline{\text { Social Disorganization Variables }}$}

$\%$ different house 5 yrs ago

$\%$ population change $2000-05$

Racial Heterogeneity Index

$\%$ children live in poverty

$\%$ single female-headed homes

\section{Civic Community Variables}

$\%$ owner-occupied housing
Mainline Church Adherence rates
$\%$ voted in 2004 election
$\%$ self-employed
$\%$ of farms $<50$ acres

$\begin{array}{lrrrrr}15.37 & 14.74 & 6.66 & 0.0 & 47.1 & 2974 \\ 47.38 & 47.03 & 15.26 & 34.7 & 97.0 & 2974 \\ 20.48 & 20.23 & 7.98 & 0.0 & 83.1 & 2824 \\ 10.46 & 10.58 & 4.76 & 0.0 & 34.8 & 2824\end{array}$

\section{All Counties Combined}

Mean Median SD $\quad$ Min $\quad$ Max $\quad$ N

$\begin{array}{cccccc}38.75 & 36.84 & 100.18 & 8.8 & 93.2 & 3140 \\ 23.45 & 23.27 & 3.39 & 0.9 & 45.1 & 3140 \\ 77.38 & 79.20 & 8.76 & 34.7 & 97.0 & 3140 \\ .45 & & & 0 & 1 & 3141\end{array}$

$\begin{array}{rrrcrr}41.10 & 40.50 & 7.48 & 9.5 & 84.6 & 3140 \\ 2.31 & 1.43 & 7.05 & -24.0 & 51.1 & 3140 \\ .22 & .14 & .20 & 0.0 & .87 & 3140 \\ 21.12 & 19.90 & 8.45 & 0.0 & 56.4 & 3139 \\ 14.94 & 13.74 & 5.81 & 2.3 & 44.6 & 3138\end{array}$

* SD designates the standard deviation; Max indicates the highest value found; Min indicates the lowest value found; $N$ indicates the number of counties with valid data on that variable.

$\begin{array}{llrrrl}73.95 & 75.30 & 7.79 & 0.0 & 89.9 & 3139 \\ 141.69 & 108.17 & 113.62 & 0.0 & 884.0 & 3139 \\ 57.71 & 57.45 & 9.37 & 14.9 & 99.9 & 3112 \\ 28.36 & 26.59 & 11.36 & 3.2 & 75.7 & 3084 \\ 27.91 & 24.70 & 17.05 & 0.0 & 100.0 & 3077\end{array}$




\section{Explaining Crime in Metropolitan and Non-Metropolitan Communities - Wells and Weisheit}

In order to make reasonable comparisons among communities in different rural-urban contexts, the Rural-Urban Continuum Score developed by the Economic Research Service of the U.S. Department of Agriculture (ERS 2003) was recoded into a four-category classification based on its census-denoted metropolitan character and the size of the largest urban settlement in the county. These four categories are: (1) metropolitan (1089 counties classified as metropolitan in the 2000 census, generally having an urban center of at least 50,000 population); (2) nonmetropolitan-city (323 counties classified as nonmetropolitan and containing a city of at least 20,000 but less than 50,000 population); (3) nonmetropolitan-small town (1059 counties classified as nonmetropolitan and containing only smaller cities or towns of less than 20,000 but more than 2,500 population) ; and (4) nonmetropolitan-rural (670 nonmetropolitan counties containing no towns or urban settlements of at least 2,500 in population). This classification lumps all metropolitan counties together regardless of size, but distinguishes among nonmetropolitan counties according to their urban centers and presumed access to urban resources. This provides a rough but meaningful classification of widely different types of ecological contexts.

In all the statistical comparisons reported here, the unit of data and of analysis is the county. Thus, "community" is effectively being operationalized at the level of a county. This might seem an arbitrary and arguable operationalization. However, we argue it is the most plausible and useful choice for a broadly focused study of communities of widely different sizes and in widely differing ecological contexts (from densely populated urban centers to sparsely populated hinterlands). The definition of community being used here is an ecologicalinteractionist one that conceptualizes community as the socially identifiable area within which a population collectively carries out the daily activities of their individual and family lives including work, shopping, education, recreation, health care, family activities (Hawley 1950; Poplin 1972; Warren 1978; Wilkinson 1986). These necessarily cover a much larger area than the neighborhoods where people's residences are located, especially in less densely populated areas where social resources are more widely scattered. Additionally many essential social services, public organizations, and political institutions are organized at the county level, making it a meaningful unit for examination of civic community processes. Pragmatically, we note that data on many kinds of macro-level social, economic, and demographic processes are most readily available at the county level. Thus, analysis of counties allows for more extensive and inclusive comparisons (which are more likely to yield more stable and generalizable findings). Acknowledging the readily identifiable problems of a politically defined and geographically variable unit like the county and considering a variety of other possible geographic options for ecological analysis, Brown and Kandel (2006: 14) nonetheless note that "counties actually present fewer problems than most other geographies" - which suggest them as the most reasonable compromise for the type of broadly inclusive and comparative analysis provided here. 


\section{Results}

The multiple regression results for four distinct measures of crime rates are reported in Tables 2, 4, 6, and 8, with Tables 3, 5, 7, and 9 displaying the partitioning of the explained variance $\left(\mathrm{R}^{2}\right)$ in each of the former. We examine the patterns for violent crime rates first, since prior studies of social disorganization theory and civic community have mostly focused on violent crimes. Correspondingly, Table 2 shows the regression of violent crime index rates (square root of the rates per 100,000 population) on the blocks of control, social disorganization, and civic community variables. It analyzes the relative ability of these independent variables to predict variations in violent crime rates across counties, and indicates the combined and unique abilities of the two crime theories to account for community-level differences in crime.

Several things about the results in Table 2 are notable. First, the two theoretical models do pretty well in predicting variations in violent crime across counties, although the predictability of violence declines as areas become increasingly rural and less populated. The $\mathrm{R}^{2}$ value for all variables combined is .543 in metropolitan counties but only .250 in nonmetro-rural counties, with intermediate levels (.433 and .404) in nonmetro counties with cities and small towns. This pattern of declining predictability of crime rates in less urban areas has been noted in some previous research, but it is only becomes noticeable in those studies that include (and explicitly compare across) the full range of community contexts. The pattern suggests that the community factors that explain violent crime in the most urban areas are substantially less helpful in predicting crime in the most rural areas. A second notable pattern in Table 2 is that the social disorganization model does a better job of explaining violent crime variations than do civic community variables, a pattern also shown in Table 3 in the higher $\mathrm{R}^{2}$ values for the social disorganization block of variables compared with the block. It is evident in Table 2 in the consistent pattern of higher regression coefficients for four of the five social disorganization variables (residential transience, racial heterogeneity, children in poverty, and single-femaleheaded households). These results suggest that traditional notions of social disorganization as described in the "classical model" of demographic precursors of community disorganization (i.e.,

residential instability, ethnic heterogeneity, social disadvantage, family disruption) remain a very viable framework across a range of community sizes and locations.

In contrast to the social disorganization results, the regression coefficients for civic community variables present a very confused pattern, despite the appreciable $\mathrm{R}^{2}$ value shown for the civic community block in Table 3 . The signs of the coefficients for two civic community variables (owner-occupied housing and prevalence of small farms) are consistently opposite to the predictions of the theory - being positive rather than negative - and the signs of a third variable (church membership rates) are inconsistent across metro-nonmetro categories. The 
Table 2 Regressions for Violent Crime Rates by Metro-Nonmetro Categories

\begin{tabular}{|c|c|c|c|c|c|}
\hline & \multirow[b]{2}{*}{ Independent Variables: $^{\mathrm{a}}$} & \multicolumn{4}{|c|}{$\underline{\text { Dependent Variable }=\text { Violent } \text { Crime Rate }}$} \\
\hline & & $\begin{array}{l}\text { Metro } \\
\text { Counties }\end{array}$ & $\begin{array}{l}\text { Nonmetro- } \\
\text { City } \\
\text { Counties }\end{array}$ & $\begin{array}{l}\text { Nonmetro- } \\
\text { Town } \\
\text { Counties }\end{array}$ & $\begin{array}{c}\text { Nonmetro- } \\
\text { Rural } \\
\text { Counties }\end{array}$ \\
\hline .................. & $\begin{array}{l}\text { Median household } \\
\text { income }\end{array}$ & -.185 & .101 & .059 & .003 \\
\hline Control & $\begin{array}{l}\% \text { population less than } \\
18 \text { years }\end{array}$ & .031 & .076 & .012 & -.058 \\
\hline \multirow[t]{2}{*}{ Variables } & $\%$ high school grads & .076 & .028 & .082 & .182 \\
\hline & $\begin{array}{l}\text { South-nonsouth } \\
\text { (1=South) }\end{array}$ & -.001 & .119 & -.055 & -.062 \\
\hline - & $\begin{array}{l}\% \text { lived in different } \\
\text { house } 5 \text { years ago }\end{array}$ & .170 & .206 & .158 & .193 \\
\hline Social & $\begin{array}{l}\% \text { population change } \\
2000-2005\end{array}$ & .012 & -.098 & -.040 & -.042 \\
\hline Disorganization & $\begin{array}{l}\text { Racial heterogeneity } \\
\text { index }\end{array}$ & .142 & .171 & .278 & .076 \\
\hline \multirow[t]{2}{*}{ Variables } & $\begin{array}{l}\% \text { children live in } \\
\text { poverty }\end{array}$ & .064 & .401 & .150 & .074 \\
\hline & $\begin{array}{l}\% \text { single female-head } \\
\text { households }\end{array}$ & .457 & .137 & .267 & .216 \\
\hline & $\begin{array}{l}\text { \% owner-occupied } \\
\text { housing }\end{array}$ & .073 & .252 & .064 & .071 \\
\hline Civic & $\begin{array}{l}\text { Church adherence - } \\
\text { mainline }\end{array}$ & .038 & .010 & -.075 & -.227 \\
\hline Community & $\%$ voted in 2004 election & -.024 & -.080 & -.143 & -.109 \\
\hline \multirow[t]{2}{*}{ Variables } & $\begin{array}{l}\% \text { self-employment (of } \\
\text { total) }\end{array}$ & -.086 & -.096 & -.036 & -.064 \\
\hline & $\begin{array}{l}\% \text { of small farms ( }<50 \\
\text { acres) }\end{array}$ & .203 & .089 & .063 & .038 \\
\hline & $\begin{array}{c}\mathrm{R}^{2} \\
(\mathrm{~N})\end{array}$ & $\begin{array}{l}.543 \\
(1005)\end{array}$ & $\begin{array}{l}.433 \\
(301)\end{array}$ & $\begin{array}{l}.404 \\
(977)\end{array}$ & $\begin{array}{l}.250 \\
(604)\end{array}$ \\
\hline
\end{tabular}

${ }^{a}$ All coefficients displayed in the table are standardized partial regression coefficients (Betas). 
Table 3 Variance in Violent Crime Rates Explained $\left(\mathbf{R}^{2}\right)$ by Independent Variable Groups Separately by County Types

\begin{tabular}{|l|c|c|c|c|}
\cline { 2 - 5 } \multicolumn{1}{c|}{ Violent Crime rates } & \multicolumn{4}{c|}{ Groups of Independent Variables } \\
\hline County Types & $\begin{array}{c}\text { Control } \\
\text { Variables }\end{array}$ & $\begin{array}{c}\text { Controls + } \\
\text { Soc Disorg }\end{array}$ & $\begin{array}{c}\text { Controls + } \\
\text { Civic Comm. }\end{array}$ & All Variables \\
\hline Metro & $.104^{\mathrm{a}}$ & .511 & .409 & .543 \\
Nonmetro-City & .310 & .404 & .346 & .433 \\
Nonmetro-Town & .154 & .383 & .257 & .404 \\
Nonmetro-Rural & .029 & .202 & .184 & .250 \\
\hline
\end{tabular}

${ }^{a}$ Cell entries report the variance explained $\left(R^{2}\right)$ by each block (or combination of blocks) of independent variables - i.e., Control variables only; Control variables + Social Disorganization variables; Control variables + Civic Community variables; all variables combined.

signs of coefficients for two variables (voter participation and self-employment) are theoretically consistent but their magnitudes are not very large or consistent, adding little predictive utility. In sum, the violent crime regressions do not consistently support the predictions for a civic community model across types of community settings.

Tables 4 and 5 show the results of the same multiple regression analysis for property crime rates, as an alternative version of the dependent variable. In many ways the pattern of effects is similar to the results for violent crimes. For example, the explanatory power of the combined variables shows a similar decline as the size of the county decreases; the largest counties show the highest $\mathrm{R}^{2}$ value and the smallest, most rural counties show the lowest. The social disorganization model generally provides more consistent prediction of county variations in property crimes, but there is more inconsistency and variation across the metro-nonmetro categories in coefficients than in the violent crime results. Two of the variables (residential instability and single-headed family households), show theoretically consistent effects across metro-nonmetro categories, although notably the coefficients are smallest in the most rural group of counties. However, the coefficients for the other three social disorganization variables (racial heterogeneity, population change, and children in poverty) show much more inconsistent effects 
Table 4 Regressions for Property Crime Rates by Metro-Nonmetro Categories

\begin{tabular}{|c|c|c|c|c|c|}
\hline & \multirow[b]{2}{*}{ Independent Variables: $^{\mathrm{a}}$} & \multicolumn{4}{|c|}{$\underline{\text { Dependent Variable }=\text { Property } \text { Crime Rate }}$} \\
\hline & & $\begin{array}{l}\text { Metro } \\
\text { Counties }\end{array}$ & $\begin{array}{l}\text { Nonmetro- } \\
\text { City } \\
\text { Counties }\end{array}$ & $\begin{array}{l}\text { Nonmetro- } \\
\text { Town } \\
\text { Counties }\end{array}$ & $\begin{array}{c}\text { Nonmetro- } \\
\text { Rural } \\
\text { Counties }\end{array}$ \\
\hline & $\begin{array}{l}\text { Median household } \\
\text { income }\end{array}$ & -.279 & -.090 & .035 & .221 \\
\hline Control & $\begin{array}{l}\% \text { population less than } \\
18 \text { years }\end{array}$ & .097 & .212 & .085 & -.098 \\
\hline \multirow[t]{2}{*}{ Variables } & $\%$ high school grads & .145 & .115 & .191 & .224 \\
\hline & $\begin{array}{l}\text { South-nonsouth } \\
\text { (1=South) }\end{array}$ & -.010 & .146 & .015 & -.031 \\
\hline & $\begin{array}{l}\% \text { lived in different } \\
\text { house } 5 \text { years ago }\end{array}$ & .357 & .251 & .220 & .080 \\
\hline Social & $\begin{array}{l}\% \text { population change } \\
2000-2005\end{array}$ & .005 & -.059 & .071 & -.005 \\
\hline Disorganization & $\begin{array}{l}\text { Racial heterogeneity } \\
\text { index }\end{array}$ & -.039 & -.105 & .060 & -.064 \\
\hline \multirow[t]{2}{*}{ Variables } & $\begin{array}{l}\% \text { children live in } \\
\text { poverty }\end{array}$ & -.066 & .062 & .081 & .148 \\
\hline & $\begin{array}{l}\% \text { single female-head } \\
\text { households }\end{array}$ & .457 & .445 & .230 & .233 \\
\hline & $\begin{array}{l}\% \text { owner-occupied } \\
\text { housing }\end{array}$ & .105 & .065 & -.024 & .155 \\
\hline Civic & $\begin{array}{l}\text { Church adherence - } \\
\text { mainline }\end{array}$ & .062 & .119 & -.034 & -.139 \\
\hline Community & $\%$ voted in 2004 election & -.036 & .019 & -.085 & -.130 \\
\hline \multirow[t]{2}{*}{ Variables } & $\begin{array}{l}\% \text { self-employment (of } \\
\text { total) }\end{array}$ & -.235 & -.115 & -.171 & -.094 \\
\hline & $\begin{array}{l}\% \text { of small farms }(<50 \\
\text { acres) }\end{array}$ & .204 & .183 & .037 & .117 \\
\hline & $\begin{array}{l}\mathrm{R}^{2} \\
(\mathrm{~N})\end{array}$ & $\begin{array}{l}.539 \\
(1005)\end{array}$ & $\begin{array}{l}.300 \\
(301)\end{array}$ & $\begin{array}{l}.245 \\
(977)\end{array}$ & $\begin{array}{l}.213 \\
(604)\end{array}$ \\
\hline
\end{tabular}

${ }^{a}$ All coefficients displayed in the table are standardized partial regression coefficients (Betas). 
- i.e., mostly small magnitudes $(<.10)$ and reversed signs in half of the coefficients. Thus, the social disorganization model, while still plausible, is less impressive in the patterns of effects shown for property crime rates. In this case, only one social disorganization variable - percent of single- female-headed family households - shows standardized regression coefficients greater than .10 across all four categories of county size.

\section{Table 5 Variance in Property Crime Rates Explained $\left(R^{2}\right)$ by Independent Variable Groups Separately by County Types}

\begin{tabular}{|l|c|c|c|c|}
\cline { 2 - 5 } \multicolumn{1}{c|}{ Property Crime rates } & \multicolumn{4}{c|}{ Groups of Independent Variables } \\
\hline County Types & $\begin{array}{c}\text { Control } \\
\text { Variables }\end{array}$ & $\begin{array}{c}\text { Controls + } \\
\text { Soc Disorg }\end{array}$ & $\begin{array}{c}\text { Controls + } \\
\text { Civic Comm. }\end{array}$ & All Variables \\
\hline Metro & $.113^{\mathrm{a}}$ & .473 & .414 & .539 \\
Nonmetro-City & .194 & .268 & .244 & .300 \\
Nonmetro-Town & .037 & .205 & .184 & .245 \\
Nonmetro-Rural & .044 & .149 & .178 & .213 \\
\hline
\end{tabular}

${ }^{\text {a }}$ Cell entries report the variance explained $\left(\mathrm{R}^{2}\right)$ by each block (or combination of blocks) of independent variables - i.e., Control variables only; Control variables + Social Disorganization variables; Control variables + Civic Community variables; all variables combined.

The results for property crime rates continue to provide a theoretically inconsistent picture for the civic community variables. The coefficients for the home-ownership and small-farms variables continue to be opposite in sign to theoretical predictions; and the church membership and voting participation variables show a pattern of mixed effects (with frequent sign reversals and mostly small magnitudes). Notably, church membership shows substantial but opposite-insign effects on property crime rates in nonmetro-cities counties compared with nonmetro-rural counties - consistent with the theory in rural counties but contradictory to the theory in nonmetro-cities counties. Only the self-employment variable is consistent with theoretical predictions and is substantively sizeable across all four categories of counties. Overall, the civic community variables do not provide very (empirically or theoretically) consistent predictions about variations in property crime rates, either within or across metro-nonmetro categories.

Tables 6 and 7 report the multiple regression results and $\mathrm{R}^{2}$-partitions for drug arrest rates, providing a substantially different measurement of the dependent variable involving public 


\section{Explaining Crime in Metropolitan and Non-Metropolitan Communities - Wells and Weisheit}

order (rather than predatory index) crimes and using arrest (rather than reported crime) rates.

Several things in Table 6 stand in contrast to those in the tables on regression results for violent and property crime. First, the two theoretical models are much less successful overall in predicting variations in drug arrests than in violent and property crimes, with $\mathrm{R}^{2}$ values generally much smaller for the drug arrest regressions. A second divergent pattern is the similarity of explained variance in drug arrest rates across all four categories of community size from metropolitan to rural. For the drug arrest regressions, the $\mathrm{R}^{2}$ values are slightly higher in the nonmetro counties - specifically the nonmetro-cities and nonmetro-rural - than in the metropolitan counties, which is in strong contrast to the steeply declining pattern for violent and property crimes with smaller county sizes. Third, the social disorganization variables that consistently worked well for violent and property crimes are less consistent predictors of drug arrest variations. For example, the predictive importance of the family disruption variable (percent of single-female headed households) in accounting for county variation in drug arrests is substantially lower than for property and violent crime. The regression coefficient for percent single-female-headed households in predicting drug arrests in the metro areas is .13 versus a sizeable .46 for violent crimes and property crimes in the same counties; this coefficient is no longer important across all levels of community size, and similarly for the percent of children living in poverty. Moreover, the regression coefficient for racial heterogeneity now has the wrong sign in predicting drug arrest rates; more heterogeneity predicts fewer drug arrests, in contradiction to social disorganization theory.

Among the five social disorganization variables included in this analysis, only residential instability (percent who lived in a different house five years ago) has a consistently substantial effect across all categories of community size. The drug arrest regressions for the civic community variables also show considerable changes and inconsistency from the index crime rates. Home ownership now has a consistently negative coefficient (as the theory predicts), although this is substantial in size $(>.10)$ only in larger metro and nonmetro counties. The regression coefficients for church membership rates are now consistent in sign with civic community theory predictions, although not very large in size; and similarly for the selfemployment variable. However, the regression coefficients for the voter participation variable (percent voted in 2004 election) now have the wrong sign (positive rather than negative); they contradict rather than confirm the civic community model. The regression coefficients for the small-family-farms variable remain mostly in the theoretically wrong direction, positive rather than negative.

All of these changes and inconsistencies from the results for violent and property rate regressions suggests that the causal or epidemiological dynamics of drug cases may be 
International Journal of Rural Criminology, Volume 1, Issue 2 (November), 2012

Table 6 Regressions for Drug Arrest Rates by Metro-Nonmetro Categories

\begin{tabular}{|c|c|c|c|c|c|}
\hline & \multirow[b]{2}{*}{ Independent Variables: $^{\mathrm{a}}$} & \multicolumn{4}{|c|}{ Dependent Variable $=$ Drug Arrest Rate } \\
\hline & & $\begin{array}{l}\text { Metro } \\
\text { Counties }\end{array}$ & $\begin{array}{l}\text { Nonmetro- } \\
\text { City } \\
\text { Counties }\end{array}$ & $\begin{array}{l}\text { Nonmetro- } \\
\text { Town } \\
\text { Counties }\end{array}$ & $\begin{array}{c}\text { Nonmetro- } \\
\text { Rural } \\
\text { Counties }\end{array}$ \\
\hline & $\begin{array}{l}\text { Median household } \\
\text { income }\end{array}$ & -.008 & .159 & .049 & .096 \\
\hline Control & $\begin{array}{l}\% \text { population less than } \\
18 \text { years }\end{array}$ & .115 & -.006 & .061 & .028 \\
\hline \multirow[t]{2}{*}{ Variables } & $\%$ high School grads & -.075 & -.161 & -.227 & -.169 \\
\hline & $\begin{array}{l}\text { South-nonsouth } \\
\text { (1=South) }\end{array}$ & .181 & .243 & .306 & .240 \\
\hline & $\begin{array}{l}\% \text { lived in different } \\
\text { house } 5 \text { years ago }\end{array}$ & .113 & .180 & .125 & .195 \\
\hline Social & $\begin{array}{l}\% \text { population change } \\
2000-2005\end{array}$ & -.041 & -.034 & .037 & -.064 \\
\hline Disorganization & $\begin{array}{l}\text { Racial heterogeneity } \\
\text { index }\end{array}$ & -.079 & -.050 & -.033 & -.213 \\
\hline \multirow[t]{2}{*}{ Variables } & $\begin{array}{l}\% \text { children live in } \\
\text { poverty }\end{array}$ & .052 & .244 & .001 & .073 \\
\hline & $\begin{array}{l}\% \text { single female-head } \\
\text { households }\end{array}$ & .133 & .070 & -.012 & .107 \\
\hline & $\begin{array}{l}\% \text { owner-occupied } \\
\text { housing }\end{array}$ & -.149 & -.153 & -.088 & -.010 \\
\hline Civic & $\begin{array}{l}\text { Church adherence - } \\
\text { mainline }\end{array}$ & -.091 & .005 & -.128 & -.097 \\
\hline Community & $\%$ voted in 2004 election & .064 & .153 & .164 & .071 \\
\hline \multirow[t]{2}{*}{ Variables } & $\begin{array}{l}\% \text { self-employment (of } \\
\text { total) }\end{array}$ & -.065 & .031 & -.001 & -.118 \\
\hline & $\begin{array}{l}\% \text { of small farms }(<50 \\
\text { acres) }\end{array}$ & .078 & .163 & -.008 & .021 \\
\hline & $\begin{array}{c}\mathrm{R}^{2} \\
(\mathrm{~N})\end{array}$ & $\begin{array}{r}.206 \\
(934)\end{array}$ & $\begin{array}{l}.227 \\
(291)\end{array}$ & $\begin{array}{l}.204 \\
(944)\end{array}$ & $\begin{array}{l}.221 \\
(569)\end{array}$ \\
\hline
\end{tabular}

${ }^{a}$ All coefficients displayed in the table are standardized partial regression coefficients (Betas). 
Table 7 Variance in Drug Arrest Rates Explained $\left(\mathbf{R}^{2}\right)$ by Independent Variable Groups Separately by County Types

\begin{tabular}{|l|c|c|c|c|}
\cline { 2 - 5 } \multicolumn{1}{c|}{ Drug Arrest rates } & \multicolumn{4}{c|}{ Groups of Independent Variables } \\
\hline County Types & $\begin{array}{c}\text { Control } \\
\text { Variables }\end{array}$ & $\begin{array}{c}\text { Controls + } \\
\text { Soc Disorg }\end{array}$ & $\begin{array}{c}\text { Controls + } \\
\text { Civic Comm. }\end{array}$ & All Variables \\
\hline Metro & $.078^{\mathrm{a}}$ & .185 & .200 & .206 \\
Nonmetro-City & .122 & .191 & .206 & .227 \\
Nonmetro-Town & .148 & .184 & .193 & .204 \\
Nonmetro-Rural & .136 & .202 & .179 & .221 \\
\hline
\end{tabular}

${ }^{a}$ Cell entries report the variance explained $\left(\mathrm{R}^{2}\right)$ by each block (or combination of blocks) of independent variables - i.e., Control variables only; Control variables + Social Disorganization variables; Control variables + Civic Community variables; all variables combined.

significantly different from more traditional predatory street crimes, that traditional macro-level explanations of street crime may be less useful for explaining drug arrests, and that rural-urban (or metro-nometro) differences may not be quite as dramatic for public order crimes as they are for ordinary street crimes.

Tables 8 and 9 report the regression results when using juvenile arrest rates as the dependent variable. There are notable convergences and differences with regressions for the other crime measures. First, as with violent and property crime, the social disorganization and civic community variables do best at predicting juvenile arrest rates in the largest category of metropolitan counties. Beyond metro counties, the $\mathrm{R}^{2}$ values drop off noticeably in nonmetro counties and continue declining as county size gets smaller. Based on the $\mathrm{R}^{2}$ values reports in Table 9 for the separate and combined blocks of independent variables, social disorganization and civic community models seem to be about equally useful overall in predicting variations in juvenile arrest rates across counties, with civic community variables slightly better in metro counties and social disorganization variables slightly better in nonmetro counties. We note, however, that the higher $\mathrm{R}^{2}$ value for civic community variables in metro counties is obtained 
International Journal of Rural Criminology, Volume 1, Issue 2 (November), 2012

Table 8 Regressions for Juvenile Arrest Rates by Metro-Nonmetro Categories

\begin{tabular}{|c|c|c|c|c|c|}
\hline & \multirow[b]{2}{*}{ Independent Variables: $^{\mathrm{a}}$} & \multicolumn{4}{|c|}{$\underline{\text { Dependent Variable }=\text { Juvenile Arrest Rate }}$} \\
\hline & & $\begin{array}{l}\text { Metro } \\
\text { Counties }\end{array}$ & $\begin{array}{l}\text { Nonmetro- } \\
\text { City } \\
\text { Counties }\end{array}$ & $\begin{array}{l}\text { Nonmetro- } \\
\text { Town } \\
\text { Counties }\end{array}$ & $\begin{array}{c}\text { Nonmetro- } \\
\text { Rural } \\
\text { Counties }\end{array}$ \\
\hline & $\begin{array}{l}\text { Median household } \\
\text { income }\end{array}$ & -.275 & .172 & -.022 & .257 \\
\hline Control & $\begin{array}{l}\% \text { population less than } \\
18 \text { years }\end{array}$ & .270 & .192 & .250 & -.014 \\
\hline \multirow[t]{2}{*}{ Variables } & $\%$ high school grads & .176 & -.266 & .087 & -.070 \\
\hline & $\begin{array}{l}\text { South-nonsouth } \\
\text { (1=South) }\end{array}$ & -.134 & -.307 & -.247 & -.205 \\
\hline (n) & $\begin{array}{l}\% \text { lived in different } \\
\text { house } 5 \text { years ago }\end{array}$ & .123 & .239 & .157 & .172 \\
\hline Social & $\begin{array}{l}\text { \% population change } \\
2000-2005\end{array}$ & .076 & .094 & .016 & -.088 \\
\hline Disorganization & $\begin{array}{l}\text { Racial heterogeneity } \\
\text { index }\end{array}$ & .039 & .325 & .144 & .036 \\
\hline \multirow[t]{2}{*}{ Variables } & $\begin{array}{l}\% \text { children live in } \\
\text { poverty }\end{array}$ & -.036 & .294 & .098 & .206 \\
\hline & $\begin{array}{l}\% \text { single female-head } \\
\text { households }\end{array}$ & .090 & -.075 & -.017 & .134 \\
\hline 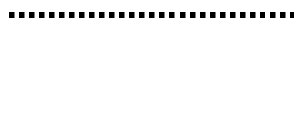 & $\begin{array}{l}\text { \% owner-occupied } \\
\text { housing }\end{array}$ & -.158 & -.019 & -.040 & .164 \\
\hline Civic & $\begin{array}{l}\text { Church adherence - } \\
\text { mainline }\end{array}$ & .031 & .272 & .005 & -.043 \\
\hline Community & $\%$ voted in 2004 election & .119 & .319 & .093 & .035 \\
\hline \multirow[t]{2}{*}{ Variables } & $\begin{array}{l}\% \text { self-employment (of } \\
\text { total) }\end{array}$ & -.280 & -.009 & -.118 & -.174 \\
\hline & $\begin{array}{l}\% \text { of small farms }(<50 \\
\text { acres) }\end{array}$ & .073 & -.057 & -.044 & -.037 \\
\hline \multicolumn{2}{|c|}{$\begin{array}{c}\mathrm{R}^{2} \\
(\mathrm{~N})\end{array}$} & $\begin{array}{r}.424 \\
(934)\end{array}$ & $\begin{array}{l}.181 \\
(291)\end{array}$ & $\begin{array}{l}.169 \\
(944)\end{array}$ & $\begin{array}{l}.144 \\
(569)\end{array}$ \\
\hline
\end{tabular}


Table 9 Variance in Juvenile Arrest Rates Explained $\left(R^{2}\right)$ by Independent Variable Groups Separately by County Types

\begin{tabular}{|l|c|c|c|c|}
\cline { 2 - 5 } \multicolumn{1}{c|}{ Juvenile Arrest rates } & \multicolumn{4}{c|}{ Groups of Independent Variables } \\
\hline County Types & $\begin{array}{c}\text { Control } \\
\text { Variables }\end{array}$ & $\begin{array}{c}\text { Controls + } \\
\text { Soc Disorg }\end{array}$ & $\begin{array}{c}\text { Controls + } \\
\text { Civic Comm. }\end{array}$ & All Variables \\
\hline Metro & $.197^{\mathrm{a}}$ & .357 & .409 & .424 \\
Nonmetro-City & .055 & .095 & .095 & .181 \\
Nonmetro-Town & .103 & .154 & .143 & .169 \\
Nonmetro-Rural & .030 & .109 & .088 & .144 \\
\hline
\end{tabular}

${ }^{a}$ Cell entries report the variance explained $\left(\mathrm{R}^{2}\right)$ by each block (or combination of blocks) of independent variables - i.e., Control variables only; Control variables + Social Disorganization variables; Control variables + Civic Community variables; all variables combined.

with two of these variables (voter participation and small-family farms) having the wrong signs on their regression coefficients. And the largest coefficients for civic community variables in the nonmetro-cities category both have theoretically incorrect signs. Thus, simply comparing $\mathrm{R}^{2}$ values can be misleading as a measure of a model's utility. Also, the total $\mathrm{R}^{2}$ values are rather low in all three nonmetro categories and the differences between them small. For these reasons, few general conclusions can be drawn about how the theoretical models compare on the juvenile arrest variable.

Taken altogether, the tables of regression results reveal the importance of taking community size into account when testing theories of crime and the hazards of limiting analysis to one particular type of community setting. They also show the importance of considering the ability of our theories to predict different forms of crime or types of crime data. For ordinary violent crimes, social disorganization theory seems more effective in predicting variance in crime rates across counties, while civic community variables show more inconsistency in sizes and signs of regression coefficients and lower levels of explained variance $\left(\mathrm{R}^{2}\right)$. However, this conclusion becomes less clear cut and certain for community differences in property crimes and no longer consistently applies in accounting for county-level differences in arrests for drugs or for juvenile arrests. 


\section{Discussion}

The goal in criminology has long been to develop a general theory of crime, a theory that would account for crime in a variety of settings and would account for a wide range of crime types. Ironically, efforts to test existing theories or to develop new ones generally utilize data from a limited number of settings (mostly metropolitan urban centers) and examine a limited number of crime types (usually violent index crimes), which greatly limits the kinds of conclusions we can draw about the theories. This study takes an alternative approach in attempting a more comprehensive and comparative assessment of the two major theoretical models of crime in rural and nonmetropolitan communities. It does this by: (1) examining two major models of crime at the same time in the same data analysis; (2) assessing the theoretical models' comparative application across the full range of community population settings (i.e., metropolitan and micropolitan, as well as rural); and (3) examining the theoretical models' utility for explaining community crime patterns with a variety of different crime measures, consistent with the broad theoretical scope of both crime models. We argue this kind of broad, inclusive, and comparative analysis is essential if we hope to develop a systematic body of cumulative knowledge about community variations in crime patterns across a range of community sizes and contexts.

First, regarding social disorganization theory, this study challenges the notion that the classical conceptualization of social disorganization, in terms of the demographic and ecological precursor conditions that lead to diminished social control over deviance, is obsolete. Social disorganization theory, in its classical version, generally fared better than civic community theory in most of our regression analyses in accounting for variance in community crime rates. Those predictor variables most consistently associated with increased crime rates in communities were the familiar social disorganization factors of residential instability (percent who had lived in a different house five years prior) and family disorganization (percent of family households headed by single female parents). At the same time, regression analysis results for social disorganization variables were mixed and inconsistent across different categories of community size and different kinds of crime rates. The social disorganization model worked best for violent crimes in metropolitan counties, consistent with prior research, but its predictions were noticeably less consistent with samples of nonmetropolitan counties and with other kinds of crime rates.

Regarding the application of social disorganization to a range of crime types, the findings reported here have much in common with those reported by Donnermeyer, Barclay, and Jobes (2002). They concluded that social disorganization did a better job of predicting variations in street crimes than in drug crimes among rural communities. Consistent with the findings of their study, we conclude that drug crimes are different from other types of crime and, consequently, may require a different explanatory model to account for their distribution across communities. This study goes beyond that of Donnermeyer et al. (2002) to include communities along the 
rural-urban continuum and to make more direct comparisons across the different population settings; however, it reaches a similar conclusion. Regarding the conditions of social disorganization and their effects on community problems, drug crimes seem to represent a different causal dynamic.

Social disorganization also fails to meet the criteria for a general theory of crime because it is unable to predict patterns of crime in the most rural communities. In the largest metropolitan areas, where it was first developed, the theory retains considerable predictive power for violent, property, and juvenile crimes. However, its diminishing power when applied to smaller and smaller communities, and its limited ability to predict patterns of drug offenses, also suggests it fails as a general theory.

This study also considers the utility of civic community theory as an explanatory perspective that, in principle, should be better than social disorganization at explaining crime in rural communities. In our analyses, however, it fared less well than social disorganization at accounting for all four types of crime in the most rural communities. As was true of social disorganization, civic community fares best when applied to the most metropolitan areas and fares most poorly when predicting drug offenses. Like social disorganization, civic community (at least in terms of the indicators of residential investment, civic engagement, and local capitalism used in this study) fails as a general theory of crime both in predicting specific patterns of effects across its core variables or its predictive power across communities of varying sizes and across crime types.

Our findings support the idea that rural communities involve somewhat different social and ecological dynamics that generate wide variations in crime rates and also suggest that drug crimes and perhaps other public order crimes, will likely involve different kinds of explanations than street crimes and other predatory crimes. This effectively means that the causal or epidemiological dynamics of crime patterns discovered in one ecological context or for one particular type of crime cannot automatically be generalized to other community settings or to other types of illegal activity.

Overall, the results of our comprehensive comparative analysis do not support the idea that either social disorganization or civic community theory provides a complete or general model of community-level crime causation. The results here show that, while similar and overlapping, the two theoretical models make separate contributions to the understanding of community crime variations and that a regression in which variables from both models are used together explains more crime rate variance than when they are considered separately. This suggests that one strategy for developing a more general and effective explanation of community crime variations might be to develop a theory that combines elements of both models in a theoretically coherent synthesis of the two frameworks that draws in elements of each. 


\section{Directions for Future Research}

This study has underlined the importance of taking community size and location into account when evaluating theories of crime, but has also raised issues for future research. We have argued that neighborhood may be an approximation of community in large urban areas but makes less sense as a proxy for community in rural areas. We chose to use county as a proxy measure of community, but are aware that such an indicator is every bit as flawed as using urban neighborhoods. The question of empirically measureable and theoretically meaningful "units of analysis" in community-level research - i.e., what exactly counts as a "community" and at what level of aggregation is it most meaningfully measured - is a question that has dogged researchers for decades. The original research on social disorganization theory was carried out on urban neighborhoods in large metropolitan cities (i.e., Chicago, New York, Boston, Los Angeles), where the urban residential neighborhood (measured by census tracts or block groups) became the de facto unit of analysis. That focus has characterized almost all subsequent research, including the work of Bursik and of Sampson, noted above. However, the original specification of social disorganization theory did not provide a clear definition of what constituted a "community" as a geographic, ecological, and social phenomenon. The universal use of "urban neighborhood" as the default definition of "community" is not explicitly grounded in theoretical conditions but is more likely the product of the availability of the units-of-data readily available in data sets.

This results in a pervasive tendency of urban-focused studies to define "community" simply as residential neighborhoods, which are small-scale geographic units defined mainly by where people sleep, get dressed, and park their cars at night. The ecological concept of community (e.g., Hawley 1950; Micklin 1984) as used in civic community research is much broader in theoretical content than this. Here community refers to an ecological setting, which is the functional area encompassing most of the important social settings in which people carry out the essential activities of their daily lives, including: working at a job, going to school, shopping, going to church, recreation, socializing with friends and family, participating in clubs and voluntary associations, going to the doctor, or getting the car repaired, as well as sleeping and getting dressed. Thus, the areas that encompass the full range of life-sustaining daily activities (and constitute community in a fuller ecological sense) are invariably much larger than the small units defined as residential neighborhoods, and may encompass quite large geographic areas. In this sense, reliance on residential neighborhoods as the unit of analysis for community-based research amounts to an analytical reduction to the study of sub-communities rather than whole communities. It also limits research on social disorganization to urban metropolitan settings where neighborhood units can be readily and meaningfully measured.

What is different about the analysis here is that it seeks to provide a more comprehensive and comparative assessment of theoretical models of crime in rural and nonmetropolitan communities. We argue this kind of broadly inclusive and comparative analysis is essential if we 


\section{Explaining Crime in Metropolitan and Non-Metropolitan Communities - Wells and Weisheit}

hope to develop a systematic body of cumulative knowledge about community variations in crime patterns across a range of community sizes and contexts - rural, micropolitan, as well as metropolitan. The common trend in available research on community-level models of crime has been on limited-focus studies that limit the analysis to specific categories or sizes of communities (usually the most metropolitan or the most rural) and to particular kinds of criminal offenses (usually to some form of violent crime). While a limited-focus approach might seem useful in simplifying or clarifying the analysis - i.e., controlling "extraneous" variation by limiting analytic attention to a homogeneous sample of similar communities and unidimensional dependent variables - it effectively results in a fragmented body of separate and incommensurable findings about community crime patterns and dynamics. Meaningful synthesis or accumulation of knowledge is difficult from a variety of separate analyses done using different analytical procedures on different samples of communities and different measures of the dependent variable. In this situation, it is difficult to systematically sort out and account for the inconsistencies, limitations, and gaps in the available studies.

In highlighting the importance of large scale comparative studies for developing useful comparative studies of the community dynamics of rural crime problems, we note that the key consideration is the use of broadly based samples of community settings that cover a broad range of community sizes and that allow comparison of the results across these distinctive subsamples. The solution is not in using more statistically rigorous estimation or significance-testing procedures that yield locally precise but non-generalizeable findings. Rather, it is in having more comprehensive data to analyze that cover a full range of community settings and dependent measures and that permit systematic comparisons across different settings and variables.

Another area for future research is to utilize these macro-level theories to more extensively examine a wide variety of social and environmental problems. This is a direct nod to the initial developers of theory, who sought to use the theory to account for such things as infant mortality, tuberculosis, and insanity. Such an approach makes sense given that crime does not occur in a vacuum, and thus we might expect social disorganization to generate a wide range of social problems. 


\section{References}

Association of Religious Data Archives (ARDA). 2002. Religious Congregations and Membership in the United States 2000 (Counties File) [Computer File). Available: http://www.thearda.com/Archive/Files/Downloads/RCMSCY_DL_DA.asp.

Barnett, C. \& Mencken, F. C. 2002. Social disorganization theory and the contextual nature of crime in nonmetropolitan counties. Rural Sociology, 67, 372-393.

Bouffard, L. A. \& Muftie, L. R. 2006. The 'rural mystique': Social disorganization and violence beyond urban communities. Western Criminology Review, 7, 56-66.

Brown, D. L. \& Kandel, W. A. 2006. Rural America through a demographic lens. Pp. 3-23 in Population Change and Rural Society, eds. W.A. Kandel and D.L. Brown. Netherlands: Springer.

Bursik, R. J. 1988. Social disorganization and theories of crime and delinquency: Problems and prospects. Criminology, 26, 519-551.

Bursik, R.J. 1999. The informal control of crime through neighborhood networks. Sociological Focus, 32, 85-97.

Bursik, R.J. \& Grasmick, H. G. 1993. Neighborhoods and Crime: The Dimensions of Effective Community Control. New York: Lexington Books.

Bursik, R.J. 1995. Neighborhood-based networks and the control of crime and delinquency. Pp. 107-130 in Crime and Public Policy: Putting Theory to Works, edited by Hugh D. Barlow. Boulder, CO: Westview Press.

Byrne, J. M. \& Sampson, R. J. (eds.). 1986. The Social Ecology of Crime. New York: SpringerVerlag.

Cancino, J. M. 2003. Breaking from orthodoxy: The effects of social disorganization on perceived burglary in nonmetropolitan communities. American Journal of Criminal Justice, $28,125-145$.

Donnermeyer, J. F., Barclay, E. M., \& Jobes, P. C. 2002. Drug-related offenses and the structure of communities in rural Australia. Substance Use \& Misuse, 37, 631-661.

Economic Research Service (ERS). 2003. Rural-Urban Continuum Codes [Computer File]. Washington, DC: U.S. Department of Agriculture, Economic Research. Available: http://www.ers.usda.gov/Briefing/Rurality/RuralUrbCon/ 


\section{Explaining Crime in Metropolitan and Non-Metropolitan Communities - Wells and Weisheit}

ESRI. 2003. Sourcebook America 2003. [Data CD]. Redlands, CA: ESRI Business Information Solutions.

Federal Bureau of Investigation (FBI). 2005. Uniform Crime Reporting Program Data [United States]: County-Level Detailed Arrest and Offense Data, 2003 [computer file]. ICPSR04360-v1. Ann Arbor, MI: Inter-University Consortium for Political and Social Research [producer and distributor]. 2005-12-06.

Federal Bureau of Investigation (FBI). 2006. Uniform Crime Reporting Program Data [United States]: County-Level Detailed Arrest and Offense Data, 2004 [computer file]. ICPSR04466-v1. Ann Arbor, MI: Inter-University Consortium for Political and Social Research [producer and distributor]. 2006-07-26.

Federal Bureau of Investigation (FBI). 2007. Uniform Crime Reporting Program Data [United States]: County-Level Detailed Arrest and Offense Data, 2005 [computer file]. ICPSR04717-v1. Ann Arbor, MI: Inter-University Consortium for Political and Social Research [producer and distributor]. 2007-07-24.

Finke, R. \& Scheitle, C. P. 2005. Accounting for the uncounted: Computing correctives for the 2000 RCMS data. Review of Religious Research, 47, 5-22.

Greene, J. R. \& Mastrofski, S. D. (eds). 1991. Community Policing: Rhetoric or Reality. New York: Praeger.

Hawley, A. H. 1950. Human Ecology: A Theory of Community Structure. New York: Ronald Press.

Hunter, A. 1985. Private, parochial and public social orders: The problem of crime and incivility in urban communities. Pp. 230-242 in G. Suttles and M. Zald (eds.), The Challenge of Social Control. Norwood, NJ: Ablex.

Inter-University Consortium for Political and Social Research (ICPSR). 2007. County Characteristics, 2000-2007, United States [Computer File]. Ann Arbor, MI: InterUniversity Consortium for Political and Social Research [producer and distributor]. 2007$10-24$.

Jobs, P. C., Barclay, E., Weinand, H. \& Donnermeyer, J. F. 2004. A structural analysis of social disorganization and crime in rural communities in Australia. The Australian and New Zealand Journal of Criminology, 37, 114-140.

Kasarda, J. D. \& Janowitz, M. 1974. Community attachment in mass society. American Sociological Review, 39, 328-339. 
Kaylen, M. T. \& Pridemore, W. A. 2011. A reassessment of the association between social disorganization and youth violence in rural America. Social Science Quarterly, 92, 9781001 .

Kposowa, A., Brealt, K., \& Harrison, B. 1995. Reassessing the structural covariates of violent and property crimes in the USA: A county level analysis. British Journal of Criminology, $46,79-105$.

Lee, M. R. 2006. The religious institutional base and violent crime in rural areas. Journal for the Scientific Study of Religion, 45, 309-324.

Lee, M. R. 2008. Civic community in the hinterland: Toward a theory of rural social structure and violence. Criminology, 46, 447-478.

Lee, M. R. \& Bartkowski, J. P. 2004a. Love thy neighbor? Moral communities, civic engagement, and juvenile homicide in rural areas. Social Forces, 82, 1001-1035.

Lee, M. R. \& Bartkowski, J. P. 2004b. Civic participation, regional subcultures, and violence: The differential effects of secular and religious participation on adult and juvenile homicide in nonmetro communities. Homicide Studies, 8, 5-39.

Lee, M. R., Maume, M. O., \& Ousey, G. C. 2003. Social isolation and lethal violence across the metro-nonmetro divide: The effects of socioeconomic disadvantage and poverty concentration on homicide. Rural Sociology, 68, 107-131.

Lee, M. R. \& Ousey, G. C. 2001. Examining the link between small manufacturing, socioeconomic deprivation, and crime rates in nonmetropolitan communities. The Sociological Quarterly, 42, 581-602.

Lee, M. R. \& Thomas, S. A. 2010. Civic community, population change, and violent crime in rural communities. Journal of Research in Crime and Delinquency, 47, 118-147.

Lyson, T. A., Torres, R. J., \& Welsh, R. 2001. Scale of agricultural production, civic engagement, and community welfare. Social Forces, 80, 311-327.

Massey, D. 2001. The prodigal paradigm returns: Ecology comes back to sociology. In A. Booth \& A.C. Crouter (eds.), Does It Take a Village? Community Effects on Children, Adolescents, and Families, Mahwah, NJ: Lawrence Erlbaum.

Micklin, M. 1984. The ecological perspective in the social sciences: A comparative overview. Pp. 51-90 in H. Micklin and H.M. Choldin (eds.), Sociological Human Ecology:

Contemporary Issues and Applications. Boulder, CO: Westview. 


\section{Explaining Crime in Metropolitan and Non-Metropolitan Communities - Wells and Weisheit}

Osgood, D. W. \& Chambers, J. M. 2000. Social disorganization outside the metropolis: An analysis of rural youth violence. Criminology, 38, 81-115.

Ousey, G. C. \& Lee, M. R. 2010. Whose civic community? Testing alternative hypotheses of the relationship between civic community and racial inequality in arrest rates. Sociological Spectrum, 30, 550-579.

Park, R. E. 1936. Human ecology. American Journal of Sociology, 3, 3-15.

Park, R. E., Burgess, E. W., \& McKenzie, R. D. 1925. The City. Chicago: University of Chicago Press.

Petee, T. A. \& Kowalski, G. S. 1993. Modeling rural violent crime rates: A test of social disorganization theory. Sociological Focus, 26, 87-89.

Poplin, D. E. 1972. Communities: A Survey of Theories and Methods of Research. New York: Macmillan.

Reiss, A. J. \& Tonry, M. (eds.). 1986. Communities and Crime. Chicago: University of Chicago Press.

Sampson, R. J. 1987. Communities and crime. In M. R. Gottfredson \& T. Hirschi (eds.), Newbury Park, Positive Criminology. CA: Sage.

Sampson, R.J. 1991. Linking the micro- and macrolevel dimensions of community social organization. Social Forces, 70, 43-64.

Sampson, R.J. 1993. Linking time and place: Dynamic contextualism and the future of criminological inquiry. Journal of Research in Crime and Delinquency, 30, 426-444.

Sampson, R.J. 1999. What 'community' supplies. In R.F. Ferguson \& W.T. Dickens (eds.), Urban Problems and Community Development. Washington, DC: Brookings Institutions Press.

Sampson, R.J. 2001. How do communities undergird or undermine human development? Relevant contexts and social mechanisms. Pp. 2-30 in A. Booth and A.C. Crouter (eds.), Does It Take a Village? Community Effects on Children, Adolescents, and Families. Mahwah, NJ: Lawrence Erlbaum.

Sampson, R.J. 2002. Transcending tradition: New directions in community research, Chicago style. Criminology, 40, 213-229.

Sampson, R.J. \& W.B. Groves. 1989. Community structure and crime: Testing social disorganization theory. American Journal of Sociology, 94, 774-802. 
Sampson, R.J., S.W. Raudenbush, \& F. Earls. 1997. Neighborhoods and violent crime: A multilevel study of collective efficacy. Science, 277, 918-924.

Shaw, C. \& McKay, H. 1942. Juvenile Delinquency and Urban Areas. Chicago: University of Chicago Press.

Tolbert, C. M., Lyson, T. A., \& Irwin, M. D. 1998. Local capitalism, civic engagement, and socioeconomic well-being. Social Forces, 77, 401-428.

Tolbert, C. M., Irwin, M. D., Lyson, T. A., \& Nucci, A. R. 2002. Civic community in smalltown America: How civic welfare is influenced by local capitalism and civic engagement. Rural Sociology, 67, 90-113.

U.S. Department of Commerce. 2003. County and City Data Book: 2000. [CD-ROM]. U.S. Census Bureau, Administrative and Customer Services Division. Washington, D.C. [C1R00-CCDB-09-US]

Warren, R. L. 1978. The Community in America ( $3^{\text {rd }}$ Ed.). Chicago: Rand McNally.

Weisheit, R. A. \& Wells, L. E. 2005. Deadly violence in the heartland. Homicide Studies, 9, 5580 .

Wells, L. E. \& Weisheit, R. A. 2004. Patterns of rural and urban crime: A county-level comparison. Criminal Justice Review, 29, 1-22.

Wilkinson, K. P. 1986. In search of the community in the changing countryside. Rural Sociology, 51, 1-17. 